\title{
Tourism Image Analysis using Tourism Marketing Strategies and Tourist Satisfaction Programs in Poso Regency
}

\author{
Abdi Sakti Walenta ${ }^{1}$, Chalid Imran Musa², Basri Bado ${ }^{3}$ \\ ${ }^{1}$ Department of Economic, Universitas Negeri Makassar \\ South Sulawesi, Indonesia \\ Email: abdisaktiwalenta [AT] gmail.com \\ ${ }^{2}$ Professor, Universitas Negeri Makassar \\ South Sulawesi, Indonesia \\ Email: imranmusa1962 [AT] gmail.com \\ ${ }^{3}$ Lecture, Universitas Negeri Makassar \\ South Sulawesi, Indonesia \\ Email: basri.bado [AT] unm.ac.id
}

\begin{abstract}
This research is based on surveys result on conditions of Poso Regency Tourism which show that when compared with the government's work plans and programs to develop tourism in Poso Regency and to make it become a mainstay sector in increasing regional income, tourism marketing performance in Poso Regency has not progressed significantly. Based on this, to increase the development of the tourism sector, tourism development efforts in Poso District prioritize increasing tourism marketing and tourist satisfaction programs. These programs can be implemented if supported by cooperation between the public sector, the tourism industry and the community. Thus, the tourism sector in Poso Regency can have a high level of quality development. Because the biggest weakness that affects the tourism image of Poso Regency lies in tourist satisfaction. Which means, the weak performance of the satisfaction program in Poso Regency has resulted in the image of tourism being unable to increase visits and convince tourists to return again. Based on the survey results, this research raises how to improve tourism marketing in implementing a combination strategy of marketing, tourist satisfaction programs and tourism image. The location of this research was conducted in Poso Regency because the survey results show that in tourism marketing, the government in Poso Regency has not shown satisfactory results and attractive imaging in marketing its tourism products.
\end{abstract}

Keywords - Merging Marketing, Satisfaction and Image

\section{INTRODUCTION}

One of the business sectors that is experiencing significant progress following the development of globalization and free trade is the service business. This can be seen from the movement of the income contribution of countries which initially relied on the agricultural sector, then moved to the manufacturing industry sector, and then developed the service sector. This movement, in turn, places the service sector as the highest stage in the process of economic development (Lovelock, 2002: 7). One of the service sub-sectors that is a mainstay for development is tourism in order to improve the economy for many countries. The contribution of tourism to the improvement of the country's economy is very significant because tourism development can create business opportunities, employment and generate income, which in turn will lead to improving the welfare of the people in the country.

According to the United Nation World Tourism Organization (2017) in Lenggogeni (2017), tourism is a leading sector and makes an important contribution to the development of a region in a country, and to improve people's welfare. The direction of making the tourism sector bigger is aimed at improving the quality of destination competitiveness through tourism investment. It is believed that this will contribute to export revenues, create jobs, develop business and infrastructure.

In Indonesia the tourism sector is one of the leading sectors. This sector is currently used as a national priority. In the 2014-2019 RPJM, the tourism sector is the leading sector in the concept of NAWACITA development. In 2016, the tourism sector was ranked 4th in the contributor to Indonesia's foreign exchange with a value of Rp. 172.8 trillion after the contribution of oil, natural gas, coal and palm oil. This sector experienced positive growth, while the three leading sectors above experienced a decline. In the future, it is believed that the tourism sector will grow to become the largest contributor to added value to goods and services in Indonesia (Lenggogeni 2017). 
The survey was conducted to see how the condition of tourism in Poso Regency. The Poso Regency Government has set a target to become the main tourism icon in Central Sulawesi Province as stated in the Poso Regency Tourism Development Master Plan for 2019-2025. The head of the Poso Regency Tourism Office said that a number of improvements would be carried out by the Poso tourism office, starting from listing all tourist objects in the area, improving facilities and infrastructure, and integrating all these objects into a tour package that can be sold through local government policies.

Following the research of Liang Tang et al (2010) on the importance of icons in building tourism marketing and image, Poso Regency through the tourism office launched the tourism icon of Poso Regency as the Thousand Megaliths Tourism and supported by other icons, namely the lake and eel fish endemic to Lake Poso with the theme of tourism three dimensions (natural tourism, marine and cultural heritage).

\section{a. Tourism}

\section{LITERATURE REVIEW}

Tourism is an activity that aims to provide tourism services, provide or manage tourist objects and attractions, tourism facilities business and other businesses related in that field. Mill and Morrison in Lumsdon (1996: 4) provide a definition of tourism as a tourist activity in traveling. These activities include planning a trip, traveling to a destination, staying at a destination, returning to the place of origin, and trying to recall trips that have been made. In addition, the activities carried out may also include activities carried out during trips, shopping, and interactions with local communities.

\section{b. Tourism Marketing Strategies Tourism Marketing Merging}

Strategy is an effort made by an organization or institution to utilize its resources in order to obtain the optimum proxy. According to Kotler and Keller (2016: 47), four variables in marketing merging activities have several components, namely:

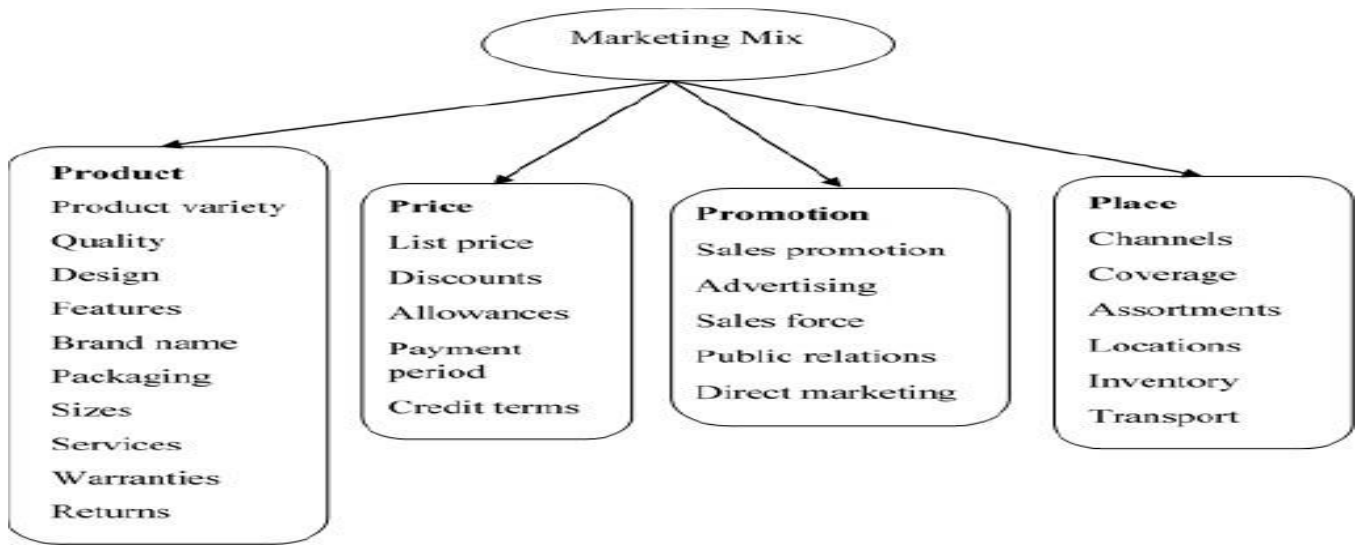

\section{Source: Kolter and Keller (2016)}

\section{c. Tourist Satisfaction}

Tourist satisfaction is important because it affects consumption during visiting and future loyalty of tourists (Hah et al., 2006; Kozak \& Rimington, 2000). More specifically, tourists who are satisfied with their previous travel experience tend to be more willing to recount destinations and recommend destinations to friends or relatives (J. Lee \& Beeler, 2009; AK Kim \& Brown, 2012). The study of tourist satisfaction was originally based on the larger concept of customer satisfaction found in a general marketing context. Satisfaction is defined as "the degree to which a person believes that experiences evoke positive feelings" (Rust \& Zaitun, 1994). Also, satisfaction is considered as "an individual's collective evaluation of experiences" (J. Lee, Kyle, \& Scoot, 2012). In addition, Akama and Kieti (2003) found that tourism satisfaction contributes to the formation of tourist loyalty, which in turn helps economic growth, through increasing the number of tourists and increasing the income of the tourism sector (Luc Vérain, 2015).

According to Day, quoted by Tjiptono (2006) states that: "Customer satisfaction or dissatisfaction is a customer response to the evaluation of the discrepancy or disconfirmation that is felt between previous expectations (or other performance norms) and the actual performance of the product that is felt after its use". Meanwhile, according to Ryan "Satisfaction is seen as the suitability of needs and performance". Furthermore, Akama and Kieti said that tourist 
satisfaction is "the extent to which tourism expectations are met" (Luc Vérain, 2015).

\section{d. Tourism Image}

The image of a tourist destination determines a fundamental role in the success of a tourist destination. This is because the image of a tourist destination has a multidimensional effect for both local people and tourists. Perceptions of the image of a tourist destination affect satisfaction and the intention to visit related locations in the future, which of course depends on the ability of the tourist destination to provide unforgettable positive experiences during the tour (Beerli and Martin, 2004).

Court and Lupton (2007) in their study of tourism found clear evidence that image positively affects the intention to visit again in the future which can be equated with loyalty to tourist destinations. The results of the research by Bigne et al., (2010) also pay attention to tourists' perceptions of the relationship between the image of a destination and its behavior. Kavaratzis and Ashworth (2009) stated that the image of a destination influences tourists' decision making in terms of where they will spend their vacation and their money. The importance of the destination image to consumers allows us to think about goals from the perspective of consumers in terms of how they feel, understand, use and experience the perceived destination.

\section{METHODOLOGY}

This study has three main variables, namely: the variable merging tourism marketing with the symbol (X1), the tourist satisfaction program variable with the symbol (X2) and the tourism image variable with the symbol (Y). This research is directed at the State Civil Servants at the Poso Regional Tourism Office as compilers, implementers, people in charge of policies towards the development of the tourism sector in Poso Regency. The unit of analysis and observation unit in this study were 98 employees and staff of the Poso Regency Tourism Office.

This study aims to prove the relationship and influence between variables in improving tourism marketing performance in Poso Regency. In this study, the exogenous variables are the marketing merging and tourist satisfaction. Meanwhile, the endogenous variable is the tourism image in Poso Regency. Based on this, to verify the relationship and influence between variables is determined and then the data is processed using the Path Analysis method.

\section{FINDING AND DISCUSSION}

Table 1. The Influence of (X1) Tourism Marketing Strategy and (X2) Tourist Satisfaction Program on (Y) Partial Tourism Image Policy

Coefficients ${ }^{\mathrm{a}}$

\begin{tabular}{|c|c|c|c|c|c|}
\hline \multirow[t]{2}{*}{ Model } & \multicolumn{2}{|c|}{$\begin{array}{l}\text { Unstandardized } \\
\text { Coefficients }\end{array}$} & \multirow{2}{*}{$\begin{array}{c}\text { Standardized } \\
\text { Coefficients }\end{array}$} & \multirow[t]{2}{*}{$\mathrm{T}$} & \multirow[t]{2}{*}{ Sig. } \\
\hline & B & $\begin{array}{l}\text { Std. } \\
\text { Error }\end{array}$ & & & \\
\hline (Constant) & - -459 & 672 & & , 682 & 497 \\
\hline $\begin{array}{c}\text { X1 Tourism } \\
\text { Marketing Strategy } \\
1 \quad\end{array}$ & 768 & ,057 & , 831 & $\begin{array}{c}13,4 \\
52\end{array}$ & , 000 \\
\hline $\begin{array}{c}\text { X2 Tourist } \\
\text { Satisfaction Program }\end{array}$ & ,035 & ,054 & ,039 & $\begin{array}{c}4.98 \\
9\end{array}$ & .000 \\
\hline
\end{tabular}

Dependent Variable: Y Tourism Image Policy

From the table above, it can be seen the influence of the number of standardized coefficients. The amount of influence (X1) of the Tourism Marketing Strategy on (Y) the Tourism Image Policy is 0.831 or $83.1 \%$, for (X2) the Tourist Satisfaction Program on (Y) the Tourism Image Policy is 0.039 or $3.9 \%$.

The magnitude of influence (X1) Tourism Marketing Strategy and (X2) Tourist Satisfaction Program on (Y) Simultaneous Tourism Image Policy can be seen in the following table: 
Table 2. Effect of (X1) Tourism Marketing Strategy and (X2) Tourist Satisfaction Program on (Y) Tourism Image Policy Simultaneously

Model Summary

\begin{tabular}{|c|c|c|c|c|}
\hline $\begin{array}{c}\text { Mode } \\
1\end{array}$ & $\mathrm{R}$ & $\mathrm{R}$ Square & $\begin{array}{c}\text { Adjusted R } \\
\text { Square }\end{array}$ & $\begin{array}{c}\text { Std. Error of } \\
\text { the Estimate }\end{array}$ \\
\hline 1 &, $851^{\mathrm{a}}$ &, 724 &, 718 & 1,2766 \\
\hline
\end{tabular}

Predictors: (Constant), X2 Tourist Satisfaction Program, X1 Tourism Marketing Strategy

The table above can be seen that the R Square value is 0.724 or $72.4 \%$. This figure shows the influence of (X1) Tourism Marketing Strategy and (X2) Tourist Satisfaction Program on (Y) Tourism Image Policy Simultaneously, while the remaining $27.6 \%$ is influenced by other factors. In other words, variable (Y) Tourism Image Policy can be explained using variables (X1) Tourism Marketing Strategy and (X2) Tourist Satisfaction Program of 71.9\%, while the influence of $27.1 \%$ is caused by other variables outside the variable. (X1) Tourism Marketing Strategy and (X2) Tourist Satisfaction Program.

In determining whether the regression model is correct, it is necessary to test a hypothesis by performing the $\mathrm{F}$ test as the test results are illustrated in the following table:

Table 3. Hypothesis Testing by Performing the F test

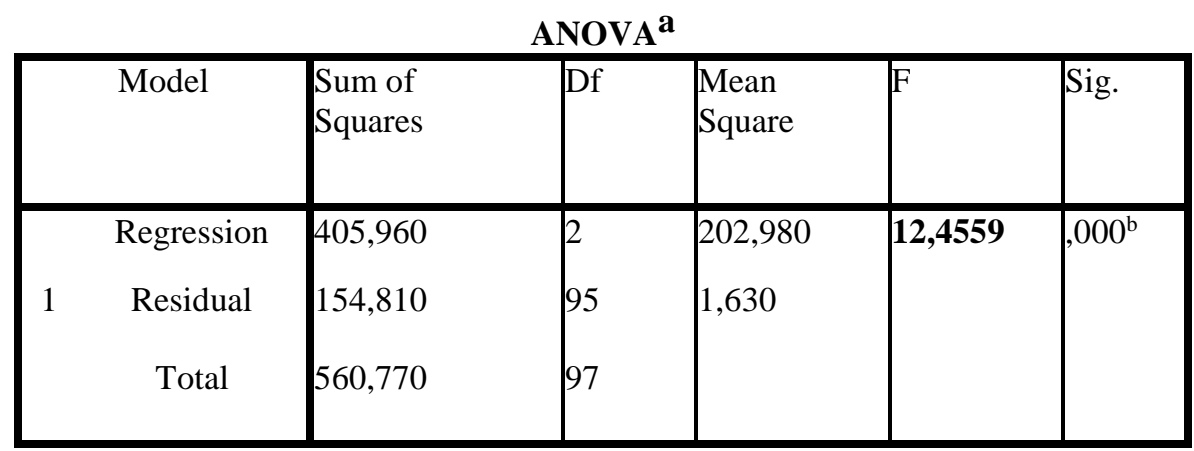

a. Dependent Variable: Y Tourism Image Policy

b. $\quad$ Predictors: (Constant), X2 Tourist Satisfaction Program, X1 Tourism Marketing Strategy

The hypothesis in this study is as follows:

H0 = There is no influence (X1) Tourism Marketing Strategy and (X2) Tourist Satisfaction Program on (Y) Tourism Image Policy

$\mathrm{Ha}=$ There is influence (X1) Tourism Marketing Strategy and (X2) Tourist Satisfaction Program on (Y) Tourism Image Policy

To determine the hypothesis testing criteria as follows:

If $\mathrm{F}$ count $>\mathrm{F}$ table, then $\mathrm{H} 0$ is rejected and $\mathrm{Ha}$ is accepted. If $\mathrm{F}$ count $<\mathrm{F}$ table, then $\mathrm{H} 0$ is accepted and $\mathrm{Ha}$ is rejected.

To determine the magnitude of the $\mathrm{F}$ table with a significance level of 0.05 and the degree of freedom (dk) with the terms of the denumerator: (number of variables $-1-\mathrm{k})=(98-1-3)=94$ (Pardede and Manurung 2014). With this provision, the $\mathrm{F}$ table number is 2.70 .

From the calculation results, it is obtained that the $\mathrm{F}$ count is $12.46>2.70 \mathrm{~F}$ table so that $\mathrm{H} 0$ is rejected and $\mathrm{Ha}$ is accepted. This means that there is an influence (X1) Tourism Marketing Strategy and (X2) Tourist Satisfaction Program on (Y) Tourism Image Policy.

\section{Influence of (X1) Tourism Marketing Strategy on (Y) Tourism Image Policy.}

To find out whether there is an effect of (X1) Tourism Marketing Strategy on

(Y) Tourism Image Policy as in the following hypothesis statement: 
$\mathrm{H} 0=$ There is no influence $(\mathrm{X} 1)$ Tourism Marketing Strategy on (Y) Tourism Image Policy

$\mathrm{Ha}=$ There is influence (X1) Tourism Marketing Strategy on (Y) Tourism Image Policy

With the provisions of the hypothesis testing criteria as follows: If $t$ count $>t$ table, then $\mathrm{H} 0$ is rejected and $\mathrm{Ha}$ is accepted.

If $\mathrm{t}<\mathrm{t}$ table, then $\mathrm{H} 0$ is accepted and $\mathrm{Ha}$ is rejected.

While to determine the amount of t table with a significance level of 0.05 and degrees of freedom (dk) with the following provisions: $\mathrm{dk}=(\mathrm{n}-1-\mathrm{k})$ or $(98-1-$

$3)=94$. With these provisions, the $t$ table number is obtained 1.66123 .

To find out the amount of the $t$ count from the processed SPSS as shown in the following table:

Table 4. Processed T Test Results

Coefficients $^{\mathbf{a}}$

\begin{tabular}{|c|c|c|c|c|c|}
\hline \multirow[t]{2}{*}{ Model } & \multicolumn{2}{|c|}{$\begin{array}{l}\text { Unstandardized } \\
\text { Coefficients }\end{array}$} & $\begin{array}{l}\text { Standardized } \\
\text { Coefficients }\end{array}$ & \multirow[t]{2}{*}{$\mathrm{T}$} & \multirow[t]{2}{*}{ Sig. } \\
\hline & B & $\begin{array}{l}\text { Std. } \\
\text { Error }\end{array}$ & Beta & & \\
\hline (Constant) &,- 459 & 672 & & -,682 & ,497 \\
\hline $\begin{array}{l}\text { X1 Tourism Marketing } \\
\text { Strategy }\end{array}$ & 768 & 057 &, 831 & 13,452 &, 000 \\
\hline $\begin{array}{ll}\text { X2 } & \text { Tourist } \\
\text { Satisfaction } & \\
\text { Program } & \end{array}$ &, 035 &, 054 &, 039 & 4.989 & .000 \\
\hline
\end{tabular}

Dependent Variable: Y Tourism Image Policy

Based on the results of the calculation, the $\mathrm{t}$ count is 13.452>1.66 $\mathrm{t}$ table, therefore $\mathrm{H} 0$ is rejected and Ha is accepted. This means that there is the influence of (X1) Tourism Marketing Strategy on (Y) Tourism Image Policy. So if the local government through the tourism office goes up / down the Tourism Marketing Strategy by 1, then the Tourism Image Policy goes up / down by 13.45 .

\section{The Influence of (X2) Tourist Satisfaction Program on (Y)Tourism Image Policy}

To find out whether there is an effect of (X2) the Tourist Satisfaction Program on (Y) the Tourism Image Policy as stated in the following hypothesis statement:

$\mathrm{H} 0=$ There is no effect $(\mathrm{X} 2)$ of the Tourist Satisfaction Program on $(\mathrm{Y})$ the Tourism Image Policy

$\mathrm{Ha}=$ There is an influence (X2) of the Tourist Satisfaction Program on (Y) the Tourism Image Policy

With the provisions of the hypothesis testing criteria as follows: If $\mathrm{t}$ count> $\mathrm{t}$ table, then $\mathrm{H} 0$ is rejected and $\mathrm{Ha}$ is accepted.

If $\mathrm{t}<\mathrm{t}$ table, then $\mathrm{HO}$ is accepted and $\mathrm{Ha}$ is rejected.

While to determine the amount of t table with a significance level of 0.05 and degrees of freedom (dk) with the following conditions: $\mathrm{dk}=(\mathrm{n}-1-\mathrm{k})$ or $(98-1-$

$3)=94$. With these provisions, the $t$ table number is obtained 1.66 .

To find out the amount of the $t$ count from the processed SPSS as shown in the following table: 
Table 5. Processed T-Test Results

Coefficients $^{\mathrm{a}}$

\begin{tabular}{|c|c|c|c|c|c|}
\hline \multirow[t]{2}{*}{ Model } & \multicolumn{2}{|c|}{$\begin{array}{l}\text { Unstandardized } \\
\text { Coefficients }\end{array}$} & \multirow{2}{*}{\begin{tabular}{|l|}
$\begin{array}{l}\text { Standardi zed } \\
\text { Coefficie } \\
\text { nts }\end{array}$ \\
Beta
\end{tabular}} & & \multirow[t]{2}{*}{ Sig. } \\
\hline & B & Std. Error & & & \\
\hline (Constant) &,- 459 & 672 & &,- 682 & ,497, \\
\hline X1 $\quad$ Tourism & & & & & \\
\hline Marketing Strategy & ,768 &, 057 & 831 & 13,452 & 000 \\
\hline $\begin{array}{l}\text { X2 Tourist } \\
\text { Satisfaction } \\
\text { Program }\end{array}$ &, 035 & 054 & 039 & 4.989 & .000 \\
\hline
\end{tabular}

a. Dependent Variable: Y Tourism Image Policy

Based on the calculation results, the $\mathrm{t}$ count is 4.989> $1.66 \mathrm{t}$ table, therefore H0di is rejected and H0di is accepted. This means that (X2) the Tourist Satisfaction Program affects (Y) the Tourism Image Policy.

\section{1) Regression Equation, Influence (X1) Tourism Marketing Strategy to (X2) Tourist Satisfaction Program}

The amount of influence (X1) of the Tourism Marketing Strategy on (X2) the Tourist Satisfaction Program can be seen in the following table:

Table 6. The Effect of (X1) Tourism Marketing Strategy on (X2) the Tourist Satisfaction Program

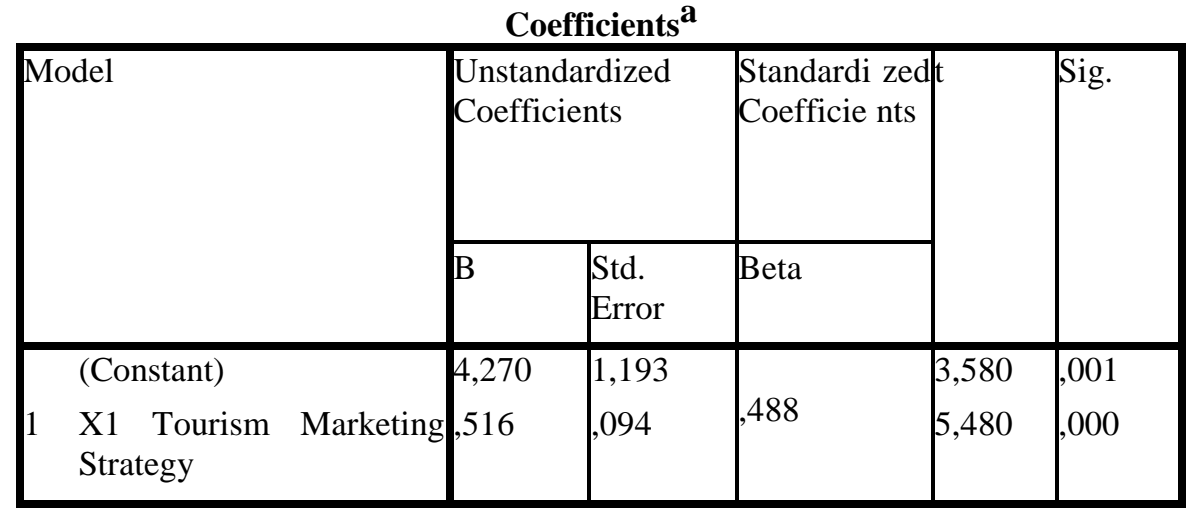

Dependent Variable: X2 Tourist Satisfaction Program

The table above can be seen the influence of the number of standardized coefficients. The amount of influence (X1) of the Tourism Marketing Strategy on (X2) the Tourist Satisfaction Program is 0.488 or $48.8 \%$.

Meanwhile, the amount of influence (X1) of the Tourism Marketing Strategy on (X2) the overall Tourist Satisfaction Program can be seen in the following table:

Table 7. The influence of (X1) Tourism Marketing Strategy on (X2) the Tourist Satisfaction Program Model Summary

\begin{tabular}{|c|c|c|c|c|}
\hline Model & $\mathrm{R}$ & $\mathrm{R}$ Square & $\begin{array}{c}\text { Adjusted R } \\
\text { Square }\end{array}$ & $\begin{array}{c}\text { Std. Error of the } \\
\text { Estimate }\end{array}$ \\
\hline 1 &, $488^{\mathrm{a}}$ &, 238 &, 230 & 2,4109093 \\
\hline
\end{tabular}

Predictors: (Constant), X1 Tourism Marketing Strategy

From the table above, it can be seen that the value of $\mathrm{R}$ Square is 0.238 or $23.8 \%$. This figure shows the amount of influence (X1) of the Tourism Marketing Strategy on (X2) the overall Tourist Satisfaction Program, while the remaining 
$76.2 \%$ is influenced by other factors. In other words, the variable (X2) Tourist Satisfaction Program can be explained by using the Tourism Marketing Strategy variable (X1) at $23.8 \%$, while the $76.2 \%$ influence is caused by other variables outside the Tourism Marketing Strategy variable (X1).

\section{2) Correlation Analysis, Correlation (X1) Tourism Marketing Strategy and (X2) Tourist Satisfaction Program}

The correlation of the processed data with SPSS between the variables (X1) Tourism Marketing Strategy and (X2) the Tourist Satisfaction Program can be seen in the following table:

Table 8. Correlation (X1) Tourism Marketing Strategy and (X2) Tourist Satisfaction Program

\begin{tabular}{|cc|c|c|}
\hline \multicolumn{4}{|c|}{ Correlations } \\
\hline $\begin{array}{c}\text { X1 Tourism } \\
\text { Marketing } \\
\text { Strategy }\end{array}$ & $\begin{array}{c}\text { X1 Tourism } \\
\text { Marketing } \\
\text { Strategy }\end{array}$ & $\begin{array}{c}\text { X2 Tourist } \\
\text { Satisfaction } \\
\text { Program }\end{array}$ \\
& Sig. (2-tailed) & 1 &, $488^{* *}$ \\
X2 Tourist & Pearson &, 000 \\
Satisfaction & Correlation & 98 & 98 \\
Program & Sig. (2-tailed) &, $488^{* *}$ & 1 \\
& $\mathrm{~N}$ &, 000 & 98 \\
\hline
\end{tabular}

**. Correlation is significant at the 0.01 level (2-tailed).

Based on the results of the data processing, the correlation between the variables (X1) of the Tourism Marketing Strategy and (X2) of the Tourist Satisfaction Program was obtained by 0.488. To interpret the number "r" the following criteria are used:

$$
\begin{aligned}
& r=(0,-0.199) \text { : very weak relationship } r=(0.2-0.399) \text { : weak relationship } \\
& r=(0.4-0.599) \text { : the relationship is strong enough } r=(0.6-0.799) \text { : strong relationship } \\
& r=(\geq 0.8) \text { : the relationship is quite strong Source: Pardede and Manurung } 2014
\end{aligned}
$$

The value of "r" of 0.488 means that the relationship between the variables (X1) of the Tourism Marketing Strategy and (X2) the Satisfaction Program is quite strong and unidirectional (because the results are positive). The correlation of the two variables is significant because the significance value ( $\mathrm{sig})$ is $0.00<0.05$. If the significance value $(\mathrm{sig})<0.05$, the relationship between the two variables is significant.

\section{a) Mediation Test with Sobel Test}

In order to find out whether the relationship through a mediating variable is significantly able to mediate in this relationship, this study will examine the effect of Tourism Marketing Strategy (X1) on Tourism Image (Y) through the Tourist Satisfaction Program (X2). In this case the Tourist Satisfaction Program (X2) is a mediator of the relationship from the Tourism Marketing Strategy (X1) to the Tourism Image (Y).

To test how much the role of the Tourist Satisfaction Program variable (X2) mediates the influence of Tourism Marketing Strategy (X1) on Tourism Image (Y), the Sobel test is used where the Sobel test uses the $\mathrm{z}$ test with the following formula:

$$
z=\frac{a b}{\sqrt{\left(\begin{array}{c}
\left.b^{2} S E^{2}\right)+\left(a^{2} S E^{2}\right) \\
a
\end{array}\right.}}
$$




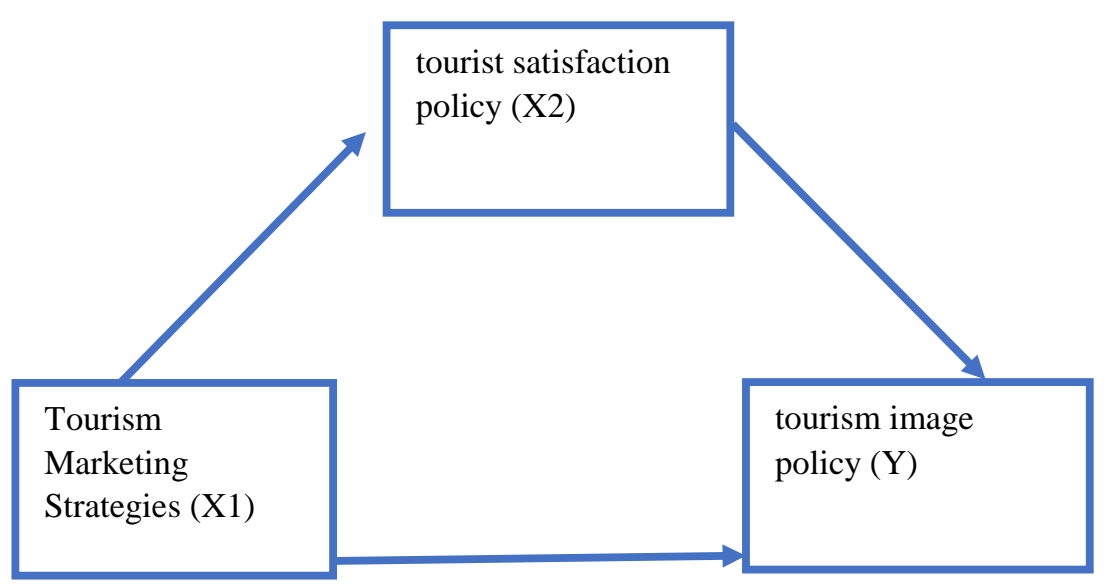

Figure 2. Sobel Test Mediation

The model above is a model formed from the results of the first and second regressions to form a path analysis model with the satisfaction variable as the mediator.

The $\mathrm{z}$ value of the sobel test cannot be generated directly with the regression results but by calculating manually with the sobel test formula as follows:

$$
\begin{aligned}
& z=\frac{a b}{\sqrt{\left(\frac{\left.b^{2} S E^{2}\right)+\left(a^{2} S E^{2}\right)}{b}\right.}} \\
& z=\frac{0,516 \times 0,350}{\sqrt{\left(0,350^{2} \times 0,094^{2}\right)+\left(0,516^{2} x 0,054^{2}\right)}} \\
& z=\frac{0,1806}{0,04309}
\end{aligned}
$$

$z=4,19$

From the results of the calculation of the Sobel test above, the value of $\mathrm{z}=$

4.191 is obtained, because the $\mathrm{z}$ value obtained is $4.191>1.66$ with a significance level of $5 \%$, it proves that the satisfaction program variable as an intermediate variable is able to mediate the relationship of the influence of tourism marketing strategies on tourism image policy.

\section{Path diagram}

The results of this study are inputted into the path diagram of the structural equation for this research as follows: 
$\mathrm{rx} 2 \mathrm{x} 1=0,488$

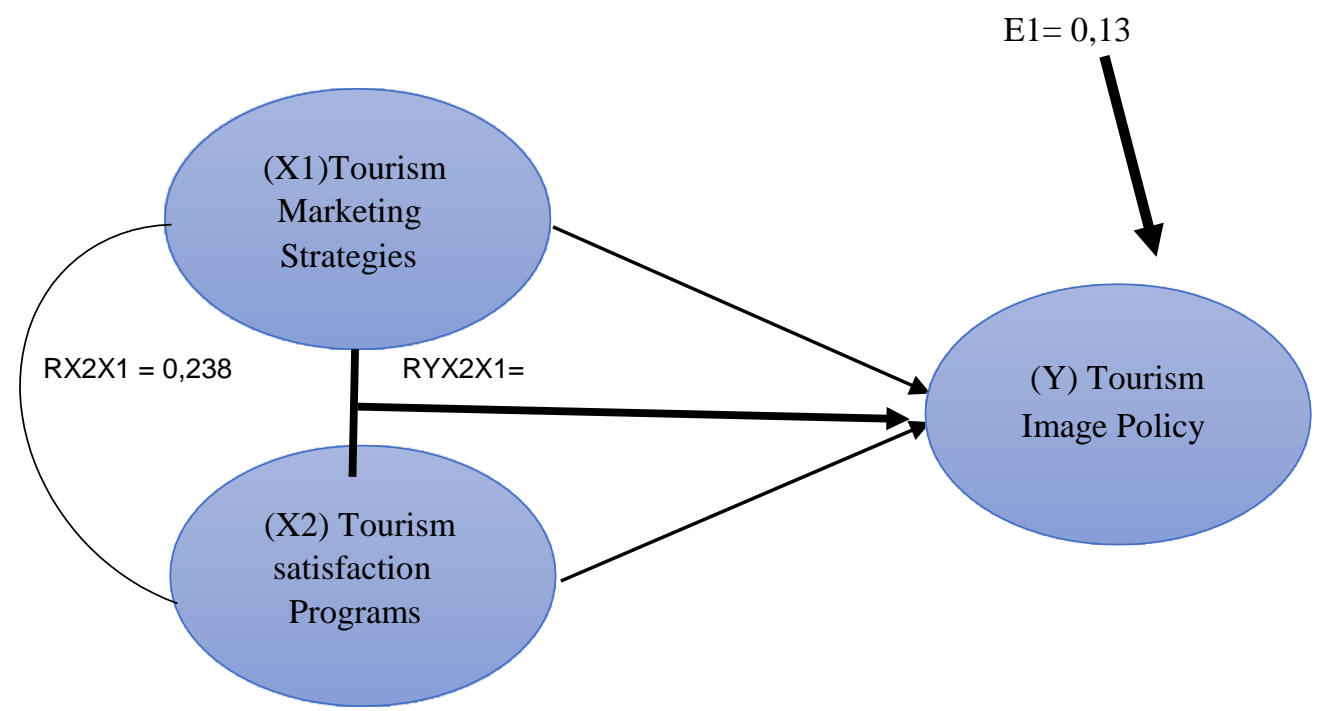

Figure 3. Path Diagram of the Structural Equation Result

The structural equation for the path diagram is as follows: $\mathrm{Y} 1=0.831 \mathrm{X} 1+0.039 \mathrm{X} 2+\mathrm{e}$

$\mathrm{Y} 2=0.724+\mathrm{e}$

$\mathrm{Y} 3=0.238+0.039+\mathrm{e}$

\section{1) Conclusion}

\section{CONCLUSION AND SUGGESTION}

From the results of the analysis and review of the above research discussion, it can be concluded that:

(1). The main objective of tourism is to influence tourists' decision making regarding travel and tourist destinations, so in this case marketing activities play an important role in creating strategies to influence tourist decisions. Even though it is impossible to influence all aspects, in the scope of tourism marketing try to build, strengthen and find the right strategy in increasing tourism marketing in Poso Regency and giving influence to the formation of a better tourism image.

(2). To increase customer satisfaction, the application of an effective and targeted marketing mix is needed to provide the required information about the products being marketed. The marketing merging is one of the key elements in shaping customer satisfaction.

(3). Customer satisfaction is a practice in which customers perceive their needs and expectations throughout the entire life cycle of developing a good product. Customer satisfaction is an important aspect of creating business value and managing customer expectations and so on can give a strong impression of the product and that strong impression can form. a positive product image in the minds of consumers. The local government of Poso Regency in collaboration with all tourism sector business actors has the responsibility to create development programs in order to satisfy tourists by ensuring that the products and services provided are in line with the demands and expectations of tourists and have a positive effect on shaping the image of tourism in the Poso Regency.

\section{2) Suggestions}

From the results of the analysis and study of the above research discussion, the researchers suggest:

(1). There are several weaknesses in the marketing strategy through the marketing mix carried out by the local government, including:

a) Tourism products, the researcher suggests, the tourism segmentation of Poso Regency emphasizes more on natural tourism, where the local government through the Tourism Office is more focused on developing and adding value to natural tourism products starting from completing the additional infrastructure needed for natural tourism objects. 
b) The place strategy, one of the main weaknesses of tourism in Poso Regency, is the lack of options for using the available modes of transportation that are used to tourist attractions, so a network of cooperation with travel agents is needed or to increase the number of car or bicycle rental services motor to be used by tourists.

C) Price, from the results of empirical research facts and in-depth interviews with tourists, the costs incurred while traveling in Poso Regency are still relatively affordable and even cheaper compared to other regions, so local governments need to take advantage of this by increasing tourism promotion.

d) Promotion, a special government policy is needed to disseminate promotional media and collaborate with the Bali and Toraja Regional Governments by building and providing information service centers on tourism in the Poso Regency area.

(2). Tourist satisfaction program. Based on empirical research facts, it is found that the biggest weaknesses of the Poso Regency regional government in formulating programs that support increased tourist satisfaction. Thus in this analysis the researchers suggest:

a) The government needs to carry out a complete data collection program relating to hotels / inns and conduct surveys to ensure the quality and standard of hotel / lodging services.

b) The government needs to carry out training programs for the professional development of the tourism workforce (guide, hotel / lodging service, chef, etc.) as a front liner.

c) The government needs to carry out adequate programs in the framework of preservation, training and development to encourage the development of regional culinary specialties for these business actors and to conduct surveys of food quality and price suitability.

d) The government needs to carry out adequate programs in developing accessibility, such as cooperation with transportation business actors (travel agents), availability of tourist destination directions, availability of responsive tourist centre services, map of destination locations, etc. in providing ease of travel for tourists in the Regional Poso.

(3). Tourism image. In general, the regional tourism image of Poso Regency is quite good. Researchers suggest that the government continues to organize cultural events and attractions and development of destination environments in order to create memorable positive experiences for tourists because perceptions of the regional image of Poso Regency affect satisfaction and intention to visit related locations in the future, which of course it depends on the ability of the tourist destination to provide positive, unforgettable experiences that are obtained during the tour in Poso Regency.

\section{REFERENCES}

[1]. Sari L, Elfindri, CREATourism Mendukung Kepariwisataan Berkelanjutan, PT. Mujur Jaya, 2017

[2]. Undang-Undang No 10 Tahun 2009

[3]. John W Creswell, Research Design Pendekatan Metode Kualitatif, Kuantitatif dan Campuran, Pustaka Pelajar, 2017

[4]. Ali Hasan, Tourism Marketing, CAPS (Center for Academic, Publishing Service, 2015 Iwan Nugroho, Ekowisata dan Pembangunan Berkelanjutan, Pustaka Pelajar, 2011 Athea Kania, Ensiklopedia Mini Manajemen Kepariwisataan, CV Angkasa, 2013

[5]. M Liga Suryadana, Vanny Octavia, Pengantar Pemasaran Pariwisata, Alfabeta, 2015

[6]. Obed Henry Mwinuka,Reviewing the Role Of Tourism Marketing In Successful Sustainable Tourist Destinations, African Journal Of Hospitality, Tourism And Leisure, volume 6 (2) - (2017)

[7]. Steve Pan, Ph.D, Sam Kim, Ph.D,Special Issue on Visual Media and Tourism, Journal of Travel and Tourism Marketing, 2017

[8]. Wen-Qi Ruan 1, Yong-Quan Li 1 and Chih-Hsing Sam Liu 2,*,Article : Measuring Tourism Risk Impacts on Destination Image, 2017

[9]. Urška Binter1, Marko Ferjan2, João Vasco Neves3, Marketing Mix And Tourism Destination Image: The Study Of Destination Bled, Slovenia,2016

[10]. Claresta Janice Jonathan1 And Riswan Efendi Tarigan2,The Effects Of E-Tourism To The Development Of Tourism Sector In Indonesia, Information System Program Study, Faculty Of Computer Science, Universitas Pelita Harapan, Commit (Communication \& Information Technology) Journal, 2016

[11]. Al-Abdallah, Ghaith Mustafa,The Impact Of Internet Marketing Research On Achieving Competitive Advantage, 
International Journal of Arts \& Sciences ; Cumberland Vol. 8, 2015

[12]. Nuno Gustavo,Marketing Management Trends In Tourism And Hospitality Industry: Facing the 21st Century Environment, International Journal Of Marketing Studies; vol. 5, no. 3; 2013

[13]. Suzanne Amaro \& Paulo Duarte, Online Travel Purchasing: A Literature Review, Journal of Travel \& Tourism Marketing, 2013

[14]. Aurelie Krahl, Social Media And Internet Tools In The Hospitality Marketing, Bachelor's Thesis, 2013

[15]. Brown, Ron T; Albright, Kendra S, The Google Online Marketing Challenge and Distributed Learning, Journal of Education for Library and Information Science ; ChicagoVol. 2013

[16]. Monica Palatkova, Travel and Torism Marketing - Review, Czech Journal Tourism, 2012.

[17]. Ivana Pavlić, The Importance Of Cognitive Determinants In Tourism Destination Image Formation, University of Dubrovnik Department of Economics and Business Economics, Croatia, 2011

[18]. Bennett, Roger, Sources and Use Of Marketing Information By Marketing Managers,Journal of Documentation ; bradford vol. 63, iss. 5, (2007)

[19]. Ispas Ana, The Tourism Destination Marketing - a Mandatory Course For The Students Of Tourism, Universitatea Transilvania Din Braov, Facultatea De Tiine Economice, str. Colina universit

[20]. Dr. Adarsh batra,Tourism Marketing For Sustainable Development, abac journal vol. 26, no.

[21]. 1 (january - april, 2006, pp. 59 - 65)

[22]. Dr. Sofia Reino, The Use of YouTube as a Tourism Marketing Tool, School of Arts, Social Sciences and Management, Queen Margaret University, UK, 2011

[23]. Danijela Križman Pavlović, Ph. D., Alen Belullo, Ph. D. Internet - An Agent Of Tourism Destination Image Formation: Content And ,correspondence Analysis Of Istria Travel Related Websites

[24]. Stanciulescu Gabriela Cecilia, City Image - As Tourism Destination, Academy of Economic Studies, Faculty of Commerce, Department of Tourism-Services, 2007

[25]. Maurice Ndalahwa Marshalls,Country Image And Its Effects In Promoting A Tourist Destination Case Study: South Africa, Master Thesis In Business Administration (MBA), 2007

[26]. He' ctor San Mart1' n, Ignacio A. Rodr1' guez del Bosque,Exploring the cognitive-affective nature of destination image and the role of psychological factors in its formation, Department of Business Administration, Cantabria University, Avda. de los Castros s/n, 39005, Santander, Spain, Tourism Management Journal, 2006

[27]. Maria Banyai, The Image of Tourism Destinations: A Case of Dracula Tourism, a thesis presented to the University of Waterloo in fulfillment of the thesis requirement for the degree of Master of Arts in Recreation and Leisure Studies - Tourism Policy and Planning, Waterloo, Ontario, Canada, 2009

[28]. Arturo Molina1*, Mar Gómez1 and David Martín-Consuegra2, Full Length Research Paper

[29]. : Tourism marketing information and destination image management, African Journal of Business Management Vol. 4. 2010

[30]. Olivia H. Jenkins*, Understanding and Measuring Tourist Destination Images, Australian Housing and Urban Research Institute, University of Queensland, St Lucia, QLD 4072, Australia, International Journal Of Tourism Research, 1999

[31]. Helena Maria Pascoal Melo1, Ana Isabel Moniz2, Francisco José Ferreira Silva3, Maria Da Graça Batista4,Tourist Destination Image And Consumer Behaviour: The Case Of The Azores, 2017

[32]. Yuan Yao, Assessing Tourist Experience Satisfaction with a Heritage Destination, Purdue University Purdue ePubs Theses and Dissertations, 2013

[33]. Valentina Della Corte*, Mauro Sciarelli, Clelia Cascella, Giovanna Del Gaudio, Customer satisfaction in Tourist Destination: The Case of Tourism Offer in The City of Naples, Journal of Investment and Management, 2015

[34]. R Rajesh*, Impact of Tourist Perceptions, Destination Image and Tourist Satisfaction on Destination Loyalty: A Conceptual Model, Pondicherry University, Puducherry, India, Revista de Turismo y Patrimonio Cultural, Vol. 11 2013

[35]. Suthathip Suanmali, Factors Affecting Tourist Satisfaction: An Empirical Study in the Northern Part of Thailand, SHS Web of Conferences 12, 2014

[36]. Rafat Beigpoor Shahrivar*, Factors that influence tourist satisfaction, Journal of Travel and Tourism Research, Special Issue Destination Management, 2012.

[37]. Fang Meng, Yodmanee Tepanon and Muzaffer Uysal, Measuring tourist satisfaction by attribute and motivation: The case of a nature-based resort, Journal of Vacation Marketing 2008

[38]. Luc Vérain, MSc, Tourist Motives, Expectations and Satisfaction, Thesis Cultural Geography, 2015

[39]. Nina K. Prebensen, Tourist Satisfaction with a Destination: Antecedents and Consequences, Finnmark College, 2004

[40]. Sepideh Doosti Bazneshina*, S.Bagher Hosseinib, Amir Reza Karimi Azeric, The Physical Variables of Tourist Areas to Increase the Tourists' Satisfaction Regarding the Sustainable Tourism Criteria: Case study of Rudsar Villages, Sefidab in Rahim Abad, Asian Conference on Environment-Behaviour Studies, 2015 